Article

\title{
The One and the Many in Bonaventure Exemplarity Explained
}

\author{
Junius Johnson
}

Honors College, Baylor University, One Bear Place \#97144, Waco, TX 76798, USA; junius_johnson@baylor.edu; Tel.: +1-254-710-7582

Academic Editor: Warren Smith

Received: 1 September 2016; Accepted: 28 November 2016; Published: 8 December 2016

\begin{abstract}
The category of exemplarity, which holds a central place in Bonaventure's thought, is in many ways a certain type of solution to the problem of the many and the one. Bonaventure's account of the relationship between the created many and the uncreated original on which they are all based is in many ways like the account that Augustine gives; but he both greatly expands upon the Augustinian account and expands it in directions that prepare for the Christocentrism that will mark the rest of his theological work. This article will explicate Bonaventure's treatment of this issue on the basis of his two most extended conversations, in the first book of his commentary on Lombard's Sentences and in the Disputed Questions on the Knowledge of Christ.
\end{abstract}

Keywords: Bonaventure; exemplarity; Christian Platonism; Augustine; Imago Dei

The Middle Ages inherited a Platonism filtered through Augustine, which both infused it with greater authority and subtly changed it in an Aristotelian direction. But through Augustine, a Platonic notion of form was preserved, with it grounding certain intuitions that would have been hard to develop from Aristotle. For Bonaventure, this is especially evident in his treatment of the question of divine ideas, and the related question of the relationship of the derived many to the original unity of divine being. This question unfolds as a question of exemplarity, that is, of the relationship between the divine being as archetype and created being as image.

This question is of central importance for Bonaventure, because it is the relationship of creatures to the Creator that will be determinative for every subsequent understanding of the creature and that will ground any possible paths for the creaturely mind to ascend to knowledge of the Creator. Thus, both theological anthropology and the historical possibility and shape of revelation stand upon the prior truth of the nature of the relationship between God and creatures.

Classically, this could be understood as a version of the problem of the many and the one, in the following way: supposing the first principle to be one (which can be variously proven from passages in Plato and Aristotle), how is it possible that it be the source of the sort of variegated multiplicity we find in the created world? This can be variously motivated: every cause is ordered to a particular effect, and so a singular cause ought to produce a singular effect ${ }^{1}$. Or, something cannot give what it does not have; yet the first principle is not the same in form as the derived many; therefore it cannot be their source. The problem is not without solution in $\mathrm{Plato}^{2}$, but for a theologian like Bonaventure it is important to insure that the solution to this problem is consonant with prior theological commitments concerning the nature of this divine-creature relationship.

1 For a thorough discussion of this principle in Aquinas and its grounding in Aristotle, see [1].

2 For one example, cf. Timaeus $29 \mathrm{~d} 6 \mathrm{ff}$., which describes the universe as model on the single Living Thing; another example is Timaeus 41a7-41d4, from which it could be argued that because each creation is less perfect than its maker, and since the unity of the form of the Good is a perfection, the highest unity could only be imaged in a vast multiplicity. 
Accordingly, Bonaventure does not come to the problem with a clean slate, but having already accepted that the category of image-and indeed, exemplarity—is central for understanding this primary relationship. And, while Bonaventure is not the only theologian to discuss exemplarity in the divine-human relationship ${ }^{3}$, he does emphasize it to an unusual degree, and the idea undoubtedly takes on a peculiar tonality in his hands ${ }^{4}$. The problem of the many and the one is thus a problem to which he already knows the answer, but that requires explication if exemplarity is to be shown to be in accord with philosophical reason.

It is marginally interesting that Bonaventure should be interacting with the Platonic version of this argument when he did not have access to the key texts; however, the point of this article is not to analyze Bonaventure's interpretation of Plato, but rather to examine his relation to an argument that is transmitted to him through the Platonist stream (his proximate source is Augustine, as will be seen shortly). What is at work here is not the text of Plato, but the logic of Plato, encountered at some remove. As a result, I will highlight a few places where the reasoning is well-rooted in Plato by pointing to a few passages that Bonaventure never read: these are to be taken as establishing that these ideas, well-founded in Christian Platonism as evidenced by Augustine's use of them, are well motivated by the Platonic text; such references do not constitute a claim that these Platonic texts are the sources of Bonaventure's thinking.

This question will be discussed from two key passages in Bonaventure: the first is in distinction 35 of his commentary on the first book of Peter Lombard's Sentences ${ }^{5}$, and the second is question four of the Disputed Questions on the Knowledge of Christ $[9]^{6}$. The former is explicitly a question about causality, and is concerned with the ability of the divine ideas to be the cause of the created many. The latter is concerned with establishing the conditions necessary for certain human knowledge, in service to a larger point about the nature of both the divine and human knowledge in the Incarnate Christ ${ }^{7}$. However, the two will be shown to paint a seamless picture of the ontology of exemplarity, precisely because it is the exemplary relationship mapped in I Sent., d. 35 that comes to the rescue of human cognition in $D Q K C$ [9], qu. 4 in order to provide the conditions necessary for certain knowledge ${ }^{8}$. These ontological pre-conditions form the dimension that opens the path to the excesses of rapture and ecstasy for which Bonaventure is so famous.

3 See for example the lengthy discussion in the Summa Halensis ([2], p. 16).

4 Hurley says: "Exemplarism indeed is in Bonaventure's thought the open sesame which explains the whole universe." [3]. Cf. Zachary Hayes: "Indeed, for Bonaventure the most properly metaphysical question is that of exemplarity" [4]. In light of this, care must be taken with J. A. Wayne Hellman's claim that “. .. Bonaventure's doctrine of exemplarism is simply the Christian teaching that all of creation comes forth from the Father and is first expressed in that expression of Himself, namely, the second person who is the Son and the medium" [5]. It is not incorrect to tie exemplarity to the doctrine of creation, as will be shown here; but it is incomplete. We must lean on the second half of the quote from Hellman, that exemplarity will begin in the doctrine of creation, but will reach beyond it into Trinity and Christology. Bonaventure himself, in a famous passage from the Hexaemeron, indicates the importance of exemplarity to his thinking: "Haec est tota nostra metaphysica: de emanatione, de exemplaritate, de consummatione" (Hex. col. 1, no. 17) [6] ["This is our whole metaphysics: concerning emanation, exemplarity, and consummation"]. Leonard Bowman reduces this statement to a primary concern with exemplarity: "These three concepts describe a process in which created beings come forth from God, reflect and express him in their being, and then return to him. They provide therefore the three points which determine the circular economy of exemplarism" [7].

5 Found in Bonaventure [8]. All translations from the commentary on the Sentences are my own.

6 Henceforth $D Q K C$.

7 Joshua Benson rightly observes that $D Q K C$ is not a text about the certitude of human knowledge; rather, this only occurs at the midpoint of the disputation as the transition from considering divine knowledge (scientia) to the wisdom of the Incarnate Christ (sapientia) [10].

8 It might seem that the claim that this is essentially a Platonic problem means that I will be disagreeing with Wendy Peterson Boring, who argues that Bonaventure's theory of knowledge, especially in this part of DQKC, is actually Aristotelian, in explicit rejection of Platonic epistemology [11]. This is not in fact the case: I am in agreement with Boring's conclusions in that article. The problem Bonaventure is addressing is, as he has received it, a Platonic one, but his response is Aristotelian (and, indeed, Augustinian) in character. 


\section{Exemplary Ideas and God}

\subsection{Augustine and Divine Ideas}

The background for the discussion of the relationship between the exemplary ideas and God is Christian Platonism. Essentially, the question is whether the forms of things (taken in a Platonic sense) are to be taken as creatures apart from God or as themselves a part of God. The classic discussion of this is question 46 of Augustine's Eighty-Three Different Questions, which treats explicitly of the things that Plato calls ideas [12] $]^{9}$. Augustine begins by stating that Plato was the first to use the name ideas for these things, but he denies that Plato could have been the first person to believe in them, because he considers them to be so important that no one who doesn't understand them could be considered wise [12]. Indeed, he asserts that no one trained in true religion could deny that such things as exemplary ideas exist ${ }^{10}$, and that it would be sacrilegious to think that they exist anywhere but in the mind of $\operatorname{God}^{11}$. And because a human cannot be created according to the same idea as a horse, there must be ideas specific to the different types of reality. Augustine concludes that given the existence of eternal ideas, participation is a necessary postulate in order that there be anything else at all ${ }^{12}$.

Augustine further describes the relation between the existing thing and its divine exemplar in Tractates on the Gospel of John [13]. There he describes the idea existing in the mind of God as life, while that which is made from the idea is not life (lest a Manichean affirmation that inanimate things have souls follow $)^{13}$ Importantly for Bonaventure, Augustine deduces that there must be some such divine idea corresponding to each thing, "for if he did not have the chest in his creative knowledge, from what source would he produce it in constructing it?"14

In Augustine, therefore, the problem was primarily ontological: while it is true that the forms or ideas are necessary for knowledge of particulars, Augustine focuses on the necessary role they have in the creation of particulars, namely as a divine template that guides the creative act. They are required for proper knowledge in a sense that is derivative upon the fact that they are necessary preconditions for creation. In essence this is to underscore that the type of idea he has in mind is a Platonic one, for it does not depend on the singulars to exist; rather, they depend on it.

\subsection{Bonaventure and Divine Ideas}

Bonaventure's discussions, by contrast, begin with the epistemological dimension, and specifically with the question of how God knows things. He is concerned to know what type of thing could be noble enough to be a worthy object of the divine intellect, and how the divine could ever stoop to looking on things outside the divine in order to know them ${ }^{15}$. While ideas or forms might seem to provide a means of knowing for God that would not involve God in the imperfection of having to

9 Augustine says that the words "form," "species," or "reasons" might equally be used.

10 "Now what person, devout and trained in true religion, although he could not yet contemplate these [ideas], would, nonetheless, dare to deny—nay, would not even acknowledge — that all things which are, i.e., that whatever things are fixed in their own order by a certain particular nature so as to exist, are produced by God as their cause? And that by that cause all things which live do live? And that the universal soundness of things and the very order whereby those things which change do repeat with a certain regularity their journeys through time are fixed and governed by the laws of the most high God? This having been established and conceded, who would dare to say that God has created all things without a rational plan? But if one cannot rightly say or believe this, it remains that all things are created on a rational plan, and man not by the same plan as horse, for it is absurd to think this. Therefore individual things are created in accord with reasons unique to them" ([12], pp. 80-81).

11 "As for these reasons, they must be thought to exist nowhere but in the very mind of the Creator. For it would be sacrilegious to suppose that he was looking at something placed outside himself when he created in accord with it what he did create" ([12], p. 81).

12 "It is by participation in these that whatever is exists in whatever manner it does exist" [12].

13 "There is, however, in wisdom itself, in a spiritual way, a certain reason by which the earth was made: this is life" (Tractate 1 , no. $17,[78: 56])$.

14 Tractate 1 , no. 17, [78:55].

15 This is not an unexpected problem if one begins with Plato's account. In the Phaedrus (246b ff.) [14], it was the inability to catch sight of something true that caused the fall of the soul into bodiliness; the gods, by contrast, are always safe 
gaze on the creatures, if the ideas are themselves creatures, one has not really solved the question, only pushed it back a step. Thus, although I Sent. dist. 35, art. un., qu. 1 asks whether ideas are to be posited in God, what is actually at stake is whether or not God knows things by means of ideas or by some other means ${ }^{16}$.

To take the objections first, the arguments collectively suggest that the claim that God knows by means of ideas limits the divine nature:

(1) If God were to know things by means of an idea, then God would not know through Godself, but through something else ${ }^{17}$. That would mean that God is dependent on something else in order to know, which is a sign of weakness and imperfection.

(2) An idea is a likeness ${ }^{18}$, and wherever there is a likeness, there must be a suitability (convenientia) between the two terms of the likeness. But on account of the great distance between God and creatures, either there is no likeness, or it is very small (minima). Therefore, either there is nothing like an idea in God, or it is imperfect; but there can be no imperfection in God, therefore etc. ${ }^{19}$.

(3) The most noble mode of knowing is to be attributed to God; but it is more noble to know a thing through its essence than through a likeness. Therefore God knows through an essence and not through a likeness ${ }^{20}$.

Because the premise that it is more noble to know things through essence than through likeness will be taken up in the conclusion, even though this objection will be to some extent rejected, it is worthwhile to pause here and examine the claim more closely. At the very least, it does not seem self-evident that it is better to know through essence than through a likeness. The claim can be multiply motivated: in the Platonic tradition, the nature of Plato's argument in the Republic against art is relevant. There, art is denigrated as a copy of a copy, and therefore multiple steps removed from reality ([15], Book X, 595a1 ff.). Imitation, therefore, is necessarily deficient. It would not take much to conclude that, in like fashion, knowledge based on shadows is not as good as knowledge based on the things that cast the shadows ${ }^{21}$.

because their minds are always nourished by the vision of the forms. Wouldn't it then follow that for God to turn from the contemplation of the highest reality would also entail a turn to imperfection?

16 Throughout both Sent. and DQKC Bonaventure will use several different terms that are meant to be rough equivalents of idea: similitudines and rationes aeternas are the most common. For the most part, I will simply use "idea" throughout this discussion.

17 “Dionysius, De divinis nominibus: 'Cognoscit divinus intellectus, sed ex se ipso et per se ipsum, non secundum ideam singulis se immittens, sed secundum unam excellentiae causam omnia noscens et continens': ergo Deus singula non cognoscit per ideam" (I Sent. dist. 35, art. un., qu. 1, contra 1) [“Dionysius, Concerning the Divine Names: "The divine intellect knows, but from itself and through itself, not applying itself to each thing according to an idea, but knowing and containing all things according to one cause of excellence.' Therefore God does not know individual things through an idea."].

18 That idea is a form of similitudo ("likeness") is argued in the second argument in favor of the position: "Sed similitudo rei, per quam res cognoscitur et producitur, est idea" (I Sent. dist. 35, art. un., qu. 1, arg. 2) ["But the likeness of a thing through which the thing is known and produces is an idea"]. It is further clarified in the response: "intelligendum, quod idea dicitur similitudo rei cognitae" (I Sent. dist. 35, art. un., qu. 1, resp.). ["it must be understood that an idea is called the likeness of the thing known"].

19 "Item, ratione videtur: quia idea dicit rationem similitudinis, et similitudo dicit rationem convenientiae; Dei autem ad creaturam, cum sit summa distantia, nulla est convenientia, aut si est, minima est: ergo aut nulla similitudo aut minima. Aut ergo non est idea in Deo, aut si est, secundum rationem imperfectum est; sed nihil imperfectum ponendum est in Deo: ergo etc." (I Sent. dist. 35, art. un., qu. 1, contra 2) ["Again, it is seen by reason: because idea indicates the notion of likeness, and likeness indicates the notion of suitability; but there is no suitability of God to the creature because there is greatest distance; or if there is suitability, it is minimal. Therefore either there is no likeness or it is minimal. Therefore either there is no idea in God, or if there is, it is imperfect according to reason; but nothing imperfect is to be posited in God, therefore etc."].

20 "Item, nobilissimus modus cognitionis est Deo attribuendus; sed cognitio per rei essentiam est nobilior quam per similitudinem rei: ergo Deus cognoscit per essentiam rei, non per similitudinem. Sed idea est similitudo, non essentia rei: et sic etc." (I Sent. dist. 35, art. un., qu. 1, contra 3) ["Again, the most noble mode of knowing is to be attributed to God; but knowledge through the essence of the thing is more noble than through the likeness of the thing. Therefore God knows through the essence of the thing, not through a likeness. But the idea is a likeness, not the essence of the thing: and thus etc."].

21 This is, of course, the conclusion of the allegory of the cave ([15], Book VII, 514a1 ff.). 
The same intuition can be motivated from Aristotle. One example would be Aquinas' discussion of Posterior Analytics II.7, where he allows that the existence of something must be known through something outside the essence or something pertaining to the essence. But as that which pertains to the essence (such as that thunder is a sound in the clouds) is nevertheless not the essence (for not every sound in the clouds is thunder), the thing is more fully known through its essence than otherwise, for only through the essence does one arrive at a proper definition ${ }^{22}$.

Interestingly, though the argument to which this premise belongs is rejected, the response to the objection does not clearly settle the question whether it is more noble to know by essence. What it actually states is that it is more noble to know by essence than by a likeness caused by the thing; it then goes on to say that there is another likeness not caused by the thing, and that knowledge according to this likeness is the most noble kind. Bonaventure appears to be taking the word "essence" in a different sense than was intended in the objection: I think he is taking essentia in the same way that veritas rei was used in the second argument for the affirmative position: that is to say, to mean the actual existence of the object. It is not clear that this is what essentia was intended to mean in the objection, however; nor is it necessary to make such an equivocation, because the concluding statement of the objection, "but the idea is a likeness, not the essence of the thing," 23 is one that Bonaventure will certainly deny, as we will see shortly.

All this allows a reading of his response to this question not as a denial of the claim that it is more noble to know by means of essence, but rather as an explanation of the way in which God's knowledge through exemplary forms is in fact knowledge through essence. This premise becomes an important step on the way to the conclusion.

(4) Ideas are only necessary for directing and regulating; but only those things that are capable of wandering need direction and regulation. God is not of this sort, therefore God does not require ideas ${ }^{24}$.

All of the preceding arguments against ideas in God are concerned with the perfection and loftiness of the divine nature. Thus, the concern that seems to push in the direction of denying ideas in God is a need to preserve the majesty of God. This is indeed a strong concern theologically, for any failure in majesty will make God fail to be that than which no greater can be conceived ${ }^{25}$. The arguments in favor of divine ideas could seem prima facie not to possess the same weight, drawn as they are from logic and psychology. However, the first argument is the very argument from Augustine's Eighty-Three Different Questions that we detailed earlier, placing the discussion explicitly in the context of Augustine's development and resolution of the problem. Given that Augustine had argued that knowledge of the divine ideas is required for true wisdom and true religion, the ensuing conflict between the theological concern and the logical ones is shown not to be an instance of reason exceeding its bounds, but rather a deeper concern rising from what might in other contexts be called "right reason". Thus, to prefer the objections because one prefers to defend the majesty of God would turn out to be to defend the majesty of God at the expense of the rationality of God.

22 "At any rate, a person who knows some thing to be must know it through something of that thing, namely, something outside of the essence of the thing or something pertaining to its essence. And he clarifies this with the example of knowing thunder to be, because we perceive a sound in the clouds-which of course pertains to the essence of thunder, albeit not the entire essence, because not every sound in the clouds is thunder-or of knowing a defect, i.e., an eclipse, of the sun or moon to be, because there is a failure of light-although not every failure of light is an eclipse" [16].

23 "Sed idea est similitudo, non essentia rei" (I Sent. dist. 35, art. un., qu. 1, contra 3).

24 "Item, idea non est necessaria nisi ad dirigendum in cognoscendo et regulandum in operando; sed nihil indiget dirigente vel regulante, nisi quod potest errare vel deviare. Deus autem nullum horum habet: ergo frustra ponuntur in Deo ideae" (I Sent. dist. 35, art. un., qu. 1, contra 4). ["Again, an idea is only necessary for directing in knowledge and regulating in operation. But nothing needs to be directed or regulated unless it is able to err and deviate. But God has none of those: therefore ideas are posited in God in vain"].

25 Bonaventure will explicitly avail himself of the Anselmian conception of divinity in many places. For one such example, see Itin . 6.2. 
a. The first argument considers the ways in which an agent may act, namely by reason, by chance, or by necessity. Chance or necessity as the source of divine agency in the act of knowing are quickly dismissed, and it is not hard to see why: chance would imply imperfection in God, and necessity would imply compulsion. Therefore God acts according to reason. In this article, this seems to mean that God acts on the basis of knowledge. That is to say, the agent must know the effect it is going to produce before that effect exists.

Now, everything known is known either through its reality or through a likeness. But nothing exists when God first knows it, for God must know it in order to be able to create it (as was just shown). Therefore things cannot be known through their reality in God. Therefore they must be known according to a likeness ${ }^{26}$.

b. The second argument is based on the logic of signification: If $X$ leads determinately to the knowledge of $Y$, then $X$ must either have within itself some likeness of $Y$ or be itself the likeness of $Y$. The protasis of the conditional may be explained as follows: leading determinately is to be opposed to leading accidentally. Therefore, only that which leads to $Y$ by something essential to itself (rather than something accidental) leads determinately to $Y$. Further to lead to the knowledge of $Y$ requires that $X$ be a likeness of $Y$, for it is the recognition of an existing likeness that causes one to move mentally from $X$ to $Y$. Thus, in order to move the mind determinately to knowledge of $Y, X$ must possess an essential likeness to $Y$.

Now, those who look upon God are led to the knowledge of all creatures ${ }^{27}$. Therefore there must either be some likeness of creatures in God, or God must be this likeness. Further, since these likenesses do not just represent things to others, but also to Godself, they are in God as in a knower. But to represent an object to the mind of a knower by means of a likeness is basically the definition of an idea; therefore there are ideas in $\mathrm{God}^{28}$.

c. The third argument is a bit odd. The first step in the argument is that (i) because things are produced by God, they are in God as in their efficient cause, and God is most truly efficient cause. It is this last claim that is difficult to understand: namely, what are we to understand the relationship to be between the fact that things are in God as in their efficient cause and the fact that God is most truly efficient cause? The most likely answer is that we are to understand this as being two ways of expressing the one result: God has produced things, therefore they are in God as in their efficient cause, which is to say that God is most truly efficient cause. The unstated assumption is that in efficient causality effects are in their causes to a significant

26 "Omne agens rationabiliter, non a casu vel ex necessitate, praecognoscit rem antequam sit; sed omnis cognoscens habet rem cognitam vel secundum veritatem vel secundum similitudinem; sed res, antequam sint, non possunt haberi a Deo secundum veritatem: ergo secundum similitudinem. Sed similitudo rei, per quam res cognoscitur et producitur, est idea: ergo etc." (I Sent. dist. 35, art. un., qu. 1, arg. 2) ["Every agent acting rationally and not by chance or necessity foreknows the thing before it exists; but every knower has the thing known either according to truth or according to a likeness. But things are not able to be had by God in truth before they exist: therefore they are had according to a likeness. But a likeness of the thing, through which the thing is known and produced, is an idea. Therefore, etc."].

27 Reading "creaturarum" for "creatorum".

28 "Item, omne quod determinate ducit in alterum cognoscendum, habet penes se similitudinem cogniti, vel ipsum est eius similitudo; sed speculum aeternum mentes se videntium ducit in cognitionem omnium creat[ura]rum, sicut dicit Augustinus, quod rectius ibi cognoscunt quam alibi: ergo restat quod in eo resident similitudines. Et constat quod sunt in eo sicut in cognoscente, quia non tantum aliis repraesentat, sed sibi; sed haec est tota ratio ideae: ergo, etc." (I Sent. dist. 35, art. un., qu. 1, arg. 3) ["Again, everything that leads determinately to the knowledge of another thing has within itself a likeness of the thing known, or is itself its likeness. But the eternal mirror leads the minds of the ones looking into it to knowledge of all creatures, as Augustine says, because they know more rightly there than elsewhere. Therefore it remains that likenesses reside in it. And it is clear that they are in it as in a knower, because it not only represents to others, but to itself. But this is the whole definition of an idea. Therefore, etc."]. 
degree. This claim in itself is not controversial ${ }^{29}$; it is in effect the guiding intuition behind Augustine's entire deduction of ideas in God.

Next, the argument asserts that (ii) because things are brought to completion by God, God is most truly final cause. This argument appears to parallel the first argument, with the only change being that now we are considering the final cause and not the efficient cause. However, there is an important asymmetry between the two arguments: Bonaventure does not say that things are in God as in their final cause (a claim he did make about efficient causality). This is a reasonable omission: given that final cause is that to which things tend, it would not make sense for things to be contained within that final cause in any straightforward sense. However, the omission does not seem entirely justified given that at the end of the Itinerarium, when the mind reaches at last its final cause (God), it comes to rest in that cause, and so is contained within it. Nevertheless, it is not contained within the final cause from the beginning, and most importantly, not at the time the causation is active, but only once that causal activity is complete. Union is the outcome and not the means of final causality.

The argument continues that (iii) in the same way, because things are known and expressed by God, God is most truly exemplar. One might expect the conclusion to be that there must be an exemplar in God; instead, the surprising conclusion is that God must be the exemplar. This argument, presented at this point in the proceedings, is not yet as strong as it will be later; but of all the arguments, it is the most like Bonaventure's eventual reply, and as such it is anticipating much of the substance of his answer. The missing argument required to get from "God contains an exemplar of all things" to "God is the exemplar of all things" will be elucidated in the response.

Finally, the argument claims (iv) that there is no exemplar unless there are ideas of the exemplified things; therefore there must be ideas in $\operatorname{God}^{30}$. This fourth premise, that there is no exemplar unless there are ideas of the exemplified things, amounts to a claim that the exemplified must be in the exemplar in an ideal form. It is presented as being entailed by the definition of the word "exemplar". Thus, in addition to what is explicitly argued here, we also have a claim about the nature of exemplarity and, ultimately, exemplary causality. It is, Bonaventure implies, much more like efficient causality than it is like final causality.

Having thus laid out the arguments on both sides, Bonaventure has to try to satisfy both the theological concern (the majesty of God) and the logical concerns. He first mentions the opinion of some theologians who claim that God does not know by means of ideas, but rather knows things by being their cause. Their idea is explained by means of two analogies: that of a point and that of unity. If a point were cognizant of its potentialities, it would know not only itself, but the lines and circumferences of which it is a necessary part. Unity, if it could think on itself, would know all numbers

29 A loose theological example would be the idea that all were able to sin in Adam because all were in some way in Adam, who was the cause of all future humans. Aristotle's examples of efficient causality seem to satisfy the idea that the effect is somehow contained in the cause: An advisor is the cause of an action, a father of a child, a maker of the thing made (Metaphysics V.2, 1013a24 ff.). However, it is not part of the definition of efficient cause, and it seems that he allows for instances that would not be of this sort: the mover causing motion (a species of change), or the fact that the same thing is the cause of contraries, depending on whether it is present or absent (the absence of a steersman, which causes a shipwreck, is Aristotle's example: a shipwreck is not contained in a steersman nor in his absence in a straightforward way) (Metaphysics V.2, 1013b11-16).

30 "Item, quia res a Deo producuntur, ideo sunt in Deo tamquam in efficiente, et Deus verissime est efficiens; similiter, quia ab ipso finiuntur, ideo verissime est finis: ergo pari ratione, quia ab ipso cognoscuntur et exprimuntur, per se ipsum Deus verissime est exemplar. Sed exemplar non est, nisi in quo sunt rerum exemplatarum ideae: ergo etc." (I Sent. dist. 35, art. un., qu. 1, arg. 4) ["Again, because things are produced by God, therefore they are in God as in the one effecting, and God is most truly efficient [cause]; similarly, because they are completed by him, therefore he is most truly end. Therefore, by equal reasoning, because they are known and expressed by him, God is, through his very self, most truly exemplar. But there is not an exemplar unless there is one in whom there are the ideas of the exemplified things. Therefore, etc."]. 
because it grounds them all ${ }^{31}$. What these two examples have in common is that both the point and unity are a necessary part of the more complex realities that they ground, and so in some sense are the cause of the subsequent realities.

Bonaventure denies this on three grounds: first, it would mean that God reasons from one thing to another, namely, by extrapolating from the divine being to all other beings. This is false, because God knows all things by one simple gaze ${ }^{32}$. Secondly, he denies that knowing something and producing something are the same type of process, which removes the ground of the analogies offered in favor of this position ${ }^{33}$. Lastly, he argues that God knows some things that are not derived from God ${ }^{34}$, which could not be the case under the proposed model.

Instead, Bonaventure's conclusion is that God does indeed know by means of ideas ${ }^{35}$. But because everything known is similar in some way to the knower ${ }^{36}$, "therefore [God] has a likeness of [the thing known], or he is himself the likeness." 37 This affirms the middle conclusion of argument (b). Furthermore, by accepting the premise of argument (3) that it is better to know by essence than by a likeness, Bonaventure can conclude that the likeness in question must be an essence.

This likeness cannot, however, be the essence of the creature. The logic that underlies this conclusion is the following:

(1) Whatever God knows, God knows by means of a simple gaze (See note 32).

(2) In all knowledge, there is an assimilation of the knower to the thing known. This similarity is grounded on a likeness of the object known in the mind of the knower.

(3) God has knowledge.

31 “Quidam enim dixerunt, quod Deus non cognoscit secundum rationem ideae, sed secundum rationem causae. Et ponunt simile: sicut si puncta cognosceret suam virtutem, cognosceret lineas et circumferentiam; similiter, si unitas haberet potentiam cognitivam, per quam converteret se super se, cognosceret omnes numeros. Per hunc modum dicunt in Deo esse. Quoniam enim Deus habet virtutem producendi omnia et cognoscit totam suam virtutem, ideo cognoscit omnia. Et hoc dicunt Dionysium sensisse, cum dixit, quod 'non secundum ideam, sed secundum unam excellentiae causam cognoscit omnia'” (I Sent. dist. 35, art. un., qu. 1, resp.) [“For some say that God does not know according to the logic of an idea, but according to the logic of cause. And they offer a metaphor: just as, if a point were to know its power, it would know lines and the circumference, similarly, if unity were to have cognitive power, through which it were thinking on itself, it would know all numbers. They say that it is like this in God. For because God has the power of producing all things and knows his entire power, therefore he knows all things. And they say that Dionysius thought this, when he said that 'he knows all things not according to an idea, but according to one cause of excellence'"'].

32 "Primum quidem, quia deus cognoscit non per collationem deveniendi a principio ad principiatum, sed simplici aspectu" (I Sent. dist. 35, art. un., qu. 1, resp.) [“First, indeed, because God does not know by a comparing of what comes from the beginning to what is begun, but by a simple gaze"].

33 "Rursus, omnis cognoscens ideo distincte producit, quia distincte cognoscit, non e converso: ergo ratio producendi non est ratio cognoscendi" (I Sent. dist. 35, art. un., qu. 1, resp.) ["Again, every knower distinctly produces because he distinctly knows, not the opposite. Therefore the logic of producing is not the logic of knowing"].

34 "Et iterum, aliqua cognoscit, quae ab ipso non sunt" (I Sent. dist. 35, art. un., qu. 1, resp.) [“And again, he knows some things which are not from him"]. What Bonaventure has in mind here is God's knowledge of sin. This is discussed to some extent in $D Q K C,([9]$, qu. 1), although that discussion leaves many questions. There is slightly more to be found in I Sent., dist. 38, art. un., qu. 1 and Brev., part 3, chap. 1. A full treatment of the question is outside the scope of the present study; it is sufficient to note that Bonaventure is consistent in maintaining that God is not the cause of evil and yet has knowledge of it, which is enough to defeat the type of knowledge he is arguing against here.

35 "Ideo est alia positio, et secundum Sanctos, et secundum philosophos, quod Deus cognoscit per ideas et habet in se rationes et similitudines rerum, quas cognoscit, in quibus non tantum ipse cognoscit, sed etiam aspicientes in eum: et has rationes vocat Augustinus ideas et causas primordiales" (I Sent. dist. 35, art. un., qu. 1, resp.) [“Therefore there is another position, both according the Saints and according to philosophers, that God knows through ideas and has the reasons and likenesses of the things that he knows in himself. Not only does he know in these likenesses, but also those gazing into him know by means of them; and Augustine calls these reasons ideas and primordial causes."].

36 "omne cognoscens, in quantum huiusmodi, simile est cognoscibili" (I Sent. dist. 35, art. un., qu. 1, resp.) [“Every knower, as such, is similar to the thing known"]. Cf. Etienne Gilson: "It is a resemblance, a sort of copy formed by the intelligence in imitation of the object which it knows, and which is, as it were, its double. This character of resemblance is as rigourously inseparable from knowledge as its character of productivity. All knowledge indeed is, in the strict sense of the term, an assimilation. The act by which an intelligence possesses itself of an object to apprehend its nature implies that this intelligence likens itself to the object, that for the moment it clothes itself with its form, and it is because it can in some way become everything that it can also know everything. It is clear then that, if every act of knowing engenders something, this something can only be a resemblance" [17].

37 "ergo habet [Deus] eius similitudinem, vel ipse est similitudo" (I Sent. dist. 35, art. un., qu. 1, resp.). 
(4) Therefore there must be some such likeness in God (from 2 and 3).

(5) These likenesses must either be caused by the things of which they are the likeness, or not.

(6) In the case of God, they cannot be caused by the objects themselves for many reasons, not least of which is that in that case God would not know by means of a simple gaze, but by multiple likenesses caused by multiple things and received through some process ${ }^{38}$.

(7) Therefore they must not be caused from outside, but already exist in God (from 5 and 6).

(8) It is more noble to know by means of essence than by a likeness ${ }^{39}$.

(9) God is most noble.

(10) Therefore in God these likenesses must belong to the category of essence (from 8 and 9).

(11) But the divine essence is simple; ${ }^{40}$ therefore there cannot be multiple essences in God, nor a division within the essence.

(12) Therefore these ideas cannot be other than the divine essence (from 10 and 11).

(13) But if they were the creaturely essences, it would follow that creatures and the Creator have the same essence, which is absurd ([9], q. 2, resp.).

(14) Therefore they cannot be the essences of things.

If they are not the essences of things, then they can only be the ideas according to which things were made, the formae exemplares. These forms always existed in God: "for all the exemplary reasons are conceived from all eternity in the womb or uterus of eternal wisdom" (Hex. col. 20, no. 5) ${ }^{41}$. For this reason also they express more truly what a creature is than any idea the creature could cause of itself: "There is another likeness that is the very expressive truth of the thing known, and a likeness to that by which it is true; and this likeness expresses the thing better than the thing expresses itself,

38 Bonaventure's express denial of a likeness caused by the object in God says: "dicendum quod est similitudo causata a veritate rei extra, et de hac verum est, quod nunquam ita perfecte exprimit rem, sicut ipsa res, si praesentialiter esset apud animam; et hac similitudine non cognoscit Deus" (I Sent. dist. 35, art. un., qu. 1, ad 3) ["It must be said that there is a likeness caused by the external truth of the thing, and concerning this likeness it is true that it never expresses a thing so perfectly as the thing itself, provided that the thing is presently in the soul. And God does not know by means of this kind of likeness."] Further, the thing could not cause knowledge of itself before it existed, so God could only know things after they had come to be: "sed omnis cognoscens habet rem cognitam vel secundum veritatem vel secundum similitatem; sed res, antequam sint, non possunt haberi a Deo secundum veritatem: ergo secundum similitudinem" (I Sent. dist. 35, art. un., qu. 1, arg. 2) ["but every knower possesses the thing known either in truth or in likeness. But things, before they exist, are not able to be had by God in truth; therefore in likeness."].

39 As previously noted above (p. 4), this premise is borrowed from the third objection. In addition on this point, cf. Hex. col. 12, no. 13: "accidentium substantialiter, quia illae rationes sunt substantia, quae est Deus." ["[it represents] accidents substantially, since those reasons are substance, which is God."] [6].

40 Simplicity (conceived under the concept unity) is very operative in this article, even if it is not thematized. In question 2 we read: "ergo cum Deus sit exemplar, in quo est omnimode status, est ergo in Deus summa unitas" (I Sent. dist. 35, art. un., qu. 2, contra 3) ["therefore since God is the exemplar in which there is complete rest, there is in God the highest unity"]. That omnimode status is important, for where there is motion, there is heterogeneity, there is less perfect and more perfect. This becomes, then, a statement about the fullness and completeness of the exemplar. For Bonaventure, this amounts to an affirmation of the consubstantiality of the Father and the Son. Further, it affirms that the divine essence has been fully expressed in the exemplar, which must then be perfectly simple if it is to reflect the full range of created realia and possibilia.

41 "Omnes enim rationes exemplares concipiuntur ab aeterno in vulva aeternae sapientiae seu utero" [6]. 
because the thing receives its method of expression from that likeness." 42 The conclusion, therefore, is that these forms are not other than the divine essence.

Now, this is a surprising conclusion. The most obvious objection, that this would blur the distinction between God and creatures too much, has already been dealt with by the denial that these likenesses are the essences of creatures. In fact, the reason they cannot be the creaturely essences is because that would entail pantheism, which Bonaventure calls "absurd". But there surely remain other possible infelicities that result from such a claim. One such would be the following: if the likenesses of creatures are not other than the divine nature, would it not follow that the creaturely likenesses are necessary?

Bonaventure's answer to this objection is also perhaps surprising: he would respond that yes, it is in fact necessary that the creaturely likenesses exist. However, one must bear in mind that in this instance what exists is the divine essence, with which the likenesses of creatures is identical, and not the creaturely essences. In fact, the divine essence existing as the exemplary forms of creatures is just the divine essence as expressive of the whole power of God; that is to say, it is the second person of the Trinity, the Word, who is in fact necessary. Therefore, the exemplary likenesses of not just actual things but also possible things must necessarily exist; that is to say, the exemplary likeness as much of Peter as of a unicorn. It does not follow, however, that either Peter or the unicorn must exist.

With this conclusion of the identity of the creaturely ideas with the divine essence Bonaventure has successfully avoided the original problematic: he has grounded divine knowledge in a way that does not require God to be dependent on created realities for that knowledge. The arguments have established the existence of ideas that are exemplary, although they have drawn upon a notion of exemplarity that is not fleshed out in this question of the Sentences. And yet, a dimension of the original problem remains, namely, how is one to account for the multiplicity of creaturely ideas, given that the divine essence is one and simple? This is the next question Bonaventure considers, along with the sense in which the ideas can be said to be plural. However, this point will be better pursued from the parallel discussion in $D Q K C$.

\section{Exemplary Ideas and Knowledge}

\subsection{Plurality of Ideas}

The Disputed Questions on the Knowledge of Christ opens with questions that pick up where the last argument from 1 Sent. began. Accordingly, question 1 is concerned to establish premise 1, that God knows by means of a simple act of understanding ([9], qu. 1, resp., p. 78). What is actually proven is

42 "Est alia similitudo, quae est ipsa veritas expressiva cogniti et eo similitudo, quo veritas; et haec similitudo melius exprimit rem, quam ipsa res se ipsam exprimat, quia res ipse accipit rationem expressionis ab illa" (I Sent. dist. 35, art. un., qu. 1, ad 3). W. Norris Clarke argues that it is not correct to say that the thing exists more truly in God than in itself, only that it is expressed more truly in God than in itself: "Clearly Thomas Aquinas cannot hold this as a metaphysical doctrine-and not even Bonaventure, if he is to remain consistent with his text quoted above. For if, as I am present in the mind of God, I do not yet possess any slightest trace of my own intrinsic act of esse, in proportion to which alone is measured all my real participation in the perfection of God, then it cannot be literally asserted that I exist, have my true being, in a higher and more perfect state in God's idea of me than in my own contingent created existence in myself. It is true that my intelligibility, the intelligible content of the divine idea of me, exists in a higher, more perfect way in God than in me; but this is still not my true being, my esse" [18]. But these are not the terms of Bonaventure's own discussion, who does not speak of real participation being measured in proportion to an intrinsic act of esse, but rather in proportion to expression: "Omnia enim vera sunt et nata sunt se exprimere per expressionem illius summi luminis; quod si cessaret influere, cetera desineret esse vera. Ideo nulla veritas creata est vera per essentiam, sed per participationem" (I Sent. dist. 8, part 1, art. 1, qu. 1, ad 4-7) ["therefore all things are true and were born to express themselves through the expression of that highest light because of which, if it were to cease to flow into them, they would cease to be true. Therefore no created truth is true by essence, but by participation."] Ewert Cousins directly contradicts Clarke's claim: "Not only do things exist actually in their divine exemplars, but they have their greatest reality there. Hence we know them most truly when we know them in the divine mind" [19]. At the very least an insistence must be pressed that to speak of intrinsic acts of esse is to invite misinterpretation of the Seraphic Doctor and to have already begun to reinterpret him in light of the Angelic Doctor. 
that God knows an infinity of objects; on the way to proving this, however, Bonaventure asserts that God knows them through an "intrinsic act".

I call it intrinsic not only because it emerges from within, but also because it has an intrinsic object, an intrinsic principle, and an intrinsic mode. I say it has an intrinsic object because, in the act of knowing, the divine vision does not look at objects outside the divinity itself. Rather, it knows all truth in as far as it gazes upon the divinity itself precisely as truth ([9], qu. 1, resp., p. 78).

Question 2 seeks to know whether God knows creatures by likenesses or their essences. This question, it can now be seen, is really asking whether the eternal ideas are the essences of creatures. The arguments on both sides seem to miss this point, precisely because they are both working with a strong opposition of likeness to essence: The two are seen as mutually exclusive. Therefore, the affirmative position, in arguing for likeness, constantly rejects essence, and the negative position, in arguing for essence, constantly rejects likeness. In the end, the arguments that God must know by a likeness are affirmed, but only after likeness has been redefined. This redefinition of likeness serves as a clarification of premise 4 above, and it is worth closer examination.

Bonaventure argues that "likeness" is able to be understood in two different ways: either as a meeting of two terms in a third, or when one thing is a likeness of another (without a third term mediating). The second type of likeness itself is of two kinds: an imitative likeness (the type of likeness a creature is relative to the Creator) and an exemplary likeness (the type of likeness of the creature that exists in the Creator). Knowledge, it turns out, requires both imitative and exemplary likeness ${ }^{43}$.

Further, knowledge is also of two kinds: that which is caused by things, and that which causes things. It is this that specifies the claim that knowledge requires both imitative and exemplary likenesses, for the knowledge caused by things requires an imitative likeness while the knowledge that causes things requires an exemplary likeness. The first of these, the knowledge caused by things, causes composition and addition in the knowing intellect by the introduction of a likeness that comes from outside the intellect, and therefore is imperfect. But the knowledge that causes things is not of this sort. It is based upon a likeness that does not come from outside the knowing intellect, and is in fact the divine intellect, the highest light, the full truth, and pure act ${ }^{44}$.

As a result, the stark opposition between knowledge by essence and knowledge by likeness with which the objections began is overcome, for God knows through likenesses that are themselves essence, the divine essence. They are not the essences of creatures, but they are still in the category of essence.

This brings us to Question 3, which resumes where the discussion in 1 Sent. left off. This question is a consideration of an objection to the common conclusion of question 2 and 1 Sent., dist. 35, art. un., qu. 1: how could the divine essence be the exemplary idea of all creatures, given that Augustine says that there must be distinct ideas according to which a man and a horse are created, but there can be no such distinction in God?

43 "To gain a better understanding of this question and of the objections, it must be noted that a likeness may be of two different types. The first type is found when two beings participate in a third reality in such a way that we can say 'a likeness is the same quality present in different beings.' But there is a likeness in another sense when one being resembles another. And this can be of two types. One is a likeness of imitation. This is seen in the way in which a creature is a likeness of the Creator. Then there is an exemplary likeness. This is found in the way in which the exemplary Idea in the Creator is a likeness of the creature. In both ways, both as imitation and as exemplary Idea, the likeness of which we speak is both expressing and expressive. And it is this sort of likeness that is required for any knowledge of reality" ([9], qu. 2, resp., p. 90).

44 "Now, there is a knowledge that causes things to be and a knowledge that is caused by things. That knowledge which is caused by things requires a likeness of imitation. Such a likeness is received from outside and therefore involves a sort of composition or addition in the knowing intellect. Hence, it involves some degree of imperfection. But the knowledge which causes things to be requires an exemplary likeness. Such a likeness does not come from outside. Hence, it implies neither composition nor any imperfection, but only absolute perfection. But the divine intellect is the supreme light, the full truth, and pure act. So, as the divine power to produce things is sufficient in itself to produce everything, so the divine light and truth is sufficient in itself to express all things. And since this expression is an intrinsic act, it is eternal. Because an expression is a form of assimilation, the divine intellect—expressing all things eternally in its supreme truth-possesses from eternity the exemplary Ideas of all creatures." ([9], qu. 2, resp., pp. 90-91). 
Bonaventure's response is twofold. His first claim is that the divine essence is one in itself, but is able in that unity to fully express all other things. This is reduced to the divine power, which is no less powerful in expressing than in creating. But if God was able to create all things with one simple act, so God can express and therefore know all things with one simple act ([9], qu. 3, resp., pp. 105-6). This might seem to run afoul of Bonaventure's claim in I Sent. dist. 35, art. un., qu. 1, resp. that producing and knowing are not the same type of process, but there is a relevant distinction to be made: while the mechanisms of producing and knowing are disanalogous, it is not the mechanisms that Bonaventure is drawing on here. Rather, he is referencing the divine ability to produce and to know, and these are in fact comparable, because identical (by simplicity).

The other part of the answer, which must deal with the problem of how it can be the case that a human and a horse are not created according to the same idea, leans on simplicity. "Something which is one in form," Bonaventure says, "can be assimilated by beings that are materially many-as is clear in the case of whiteness in a man and in a stone." ([9], qu. 3, resp., p. 106). In Bonaventure's example, there is one form of whiteness, and even though it is present in numerically distinct particulars, it is not multiplied. This is meant to be made possible by the fact that the essence in question is simple, and therefore can share itself without diminution or multiplication.

There is an obvious Aristotelian objection to this example: the whiteness of a man is not the whiteness of a stone, or more precisely, the whiteness of $A$ is not the whiteness of $B$. Whiteness is an accident that comes into being when instantiated, and is therefore multiplied in the individuals in which it inheres. But note the relation of this Aristotelian argument to Bonaventure's argument: it is not a counter-example, it is a denial of Bonaventure's premise, in the same way that it was originally meant to be a denial of Plato's premises about forms. For Aristotle tends to immanentize all forms to particulars, which is a denial of divine ideas. But Bonaventure has already accepted divine ideas: his aim here is to assert that there are at least some forms that don't work as Aristotle says that they do, a claim that will be of importance to Bonaventure's notion of participation.

Thus, he concludes that "the expression of diverse objects in or by the divine truth is not diverse in itself" ([9], qu. 3, resp., p. 106). However, from the standpoint of the object, it will be judged to be diverse, because to express a human is not the same as to express an ass. He gives two more examples to motivate the point, bringing together the divine power and the divine simplicity: the first is the example of predestination. It is not the same, he says, to predestine Peter and to predestine Paul. This is demonstrable, as the result of the first is the salvation of Peter, and the result of the second is the salvation of Paul. Yet an action that is one and the same in all respects cannot issue in different results. Therefore these two acts are not entirely the same.

The second example is even clearer: it is not the same thing to create a human as to create an angel. And yet, since the divine essence is simple, it is simple also in its actions, which means that in one act it created matter and space, humans and angels, donkeys and cats. The divine creativity is an act that is one in itself, but many in its effects; one in its source, many in its relations to things.

Of course, relations themselves, if they are taken to be real, cause distinction; it is the way the persons of the Trinity are distinguished within the Godhead. ${ }^{45}$ Therefore, these relations cannot be real in God, for if God were really related to anything outside the divinity, simplicity would be destroyed ${ }^{46}$. Therefore these relations are merely logical or conceptual in God, but real in the creatures ${ }^{47}$.

\subsection{The Influence of the Exemplary Ideas on Cognition}

It was at this point that Augustine made the claim that in order that things exist, they had to participate in the ideas. But since Bonaventure is talking about knowledge, his next question is whether

45 See Bonaventure, 1 Sent. dist. 26, art. 1, qu. 2, resp.

46 For an excellent study of the high Scholastic understanding of relations, see [20].

47 "Therefore, it must be said that the exemplary causes in God are many, not really but only conceptually and by virtue of something found not only in the subject knowing but also in the object known" ([9], qu. 3, resp., p. 106). 
it is necessary to see things in the eternal ideas in order to know things with certitude. ${ }^{48}$ The relation of the two concepts may be described as follows: Augustine is arguing that in order for things to be firmly established in the ontological order, they must participate in the divine ideas; Bonaventure is arguing that in order for things to be firmly established in the epistemological order, they must participate in the divine ideas. Like Augustine, Bonaventure will turn to the notion of participation at this point.

Bonaventure trots out an impressive number of arguments on both sides of this position: thirty-four for the idea that certitude is only possible in the eternal reasons and twenty-four against. Among the arguments in favor, Bonaventure offers eleven passages from Augustine, none of them the passage from Eighty-Three Different Questions. Then, after adding arguments from the authority of Ambrose, Gregory the Great, Anselm, Origen, the Psalms, and Aristotle, at the point when he is turning from arguments from authority to arguments from reason, he lists another five places in Augustine from which more arguments could be drawn. This is an exceptional number of passages from Augustine for Bonaventure to be citing, and shows how deeply grounded in Augustine's doctrine Bonaventure finds the divine ideas to be, and how much he sees his own take on the question to be in continuity with Augustine's understanding.

The number of questions on each side may be taken as evidence of a wide variety of opinions on the subject; accordingly, the possible solutions Bonaventure considers are also wide ranging, though he reduces them to basically three views: (1) that the ideas are the sole and total cause of certain knowledge; (2) that they provide an influence that is necessary for certain knowledge; and (3) the middle position, that they must be present as a partial cause of knowledge, but are only present in this life without clarity.

Bonaventure rules out the first view, that the eternal ideas are the sole causes of knowledge, on the basis that it would level a whole range of distinctions usually made among different types of knowledge: between knowledge in this life and the next (obscure, partial knowledge versus face-to-face knowledge, following 1 Corinthians 13:12), knowledge in the Word and knowledge of things in themselves, science and wisdom, nature and grace, reason and revelation ([9], qu. 4, resp., pp. 132-33). This view is, in Bonaventure's opinion, too strong.

The second view, that the eternal ideas merely provide an influence, is too weak. For even though on the surface it seems to assert something like participation, it doesn't account for the need the created mind has to be regulated by something unchangeable and eternal if it is to reach certitude. At this point, an interlocutor might have responded to Bonaventure that the influence of the eternal ideas provides this unchangeable, eternal stability. But Bonaventure would say that this is to misunderstand influence: the influence is not itself eternal, or unchangeable. Influence is something that proceeds, that can only be a creature, and that may come or go. It will not be strong enough to ground certain knowledge.

Therefore, Bonaventure thinks that what is required is something that is between these two. It has to be like the first position in that the eternal ideas themselves have to be involved as a cause of knowledge; but unlike the first position, they cannot be the total cause. Likewise, like the second position, these ideas cannot be present in their fullness or with clarity; but unlike the second position, they must themselves be in play in some way. Thus, the eternal reason is "involved as the regulative and motive principle, but certainly not as the sole principle nor in its full clarity." ([9], qu. 4, resp., p. 134).

So far this accords with the noted parallel between Bonaventure's epistemological argument and Augustine's ontological one. Bonaventure goes on to offer a second set of reasons why our minds, whether in this life or the next, must attain to the eternal ideas if we are to have certain knowledge. And with this second set of concerns, the distance between the ontological and epistemological orders in Bonaventure's exposition begins to shrink, revealing that his discussion has in fact also been primarily concerned with ontology all along.

48 Certitude here is not just a matter of feeling certain, but actually coming to necessary conclusions that cannot be wrong. 
The first of the additional arguments is an argument concerning the nobility of knowledge, which means that there can be no certain knowledge without an immutable object and an infallible knower ${ }^{49}$. Certain knowledge turns out to be something like a stable correspondence between the knower and the object known. This correspondence cannot be stable if the object can change, and it is not a correspondence if the knower is mistaken.

However, no creature is immutable and no created power is infallible. Thus, certain knowledge, as much of creatures as by creatures, is impossible unless these conditions can somehow be met by reference to a third thing. This is where the eternal ideas come in as light and truth: light insofar as they loan infallibility to the knower, and truth insofar as they loan immutability to the object. While it is easy to see how they do the latter (for when one sees things along with their eternal reasons, one is seeing what is necessarily and therefore immutably true about them), it is harder to see how the ideas make the created reason infallible; the intuition is probably that they bring it about that the process of reasoning proceeds from necessary principles, and therefore error is not possible.

Bonaventure's second reason why our minds need the eternal reasons is concerned with the nobility of the knower. To expound this, he turns to his division of creatures into vestiges, images, and likenesses ${ }^{50}$. This is meant to help explain that it is the higher part of human reason that is at work in certain knowledge, and that attains to the eternal reasons.

He points out that in any action of a creature, whether it be vestige, likeness, or image, God cooperates. In the acts of vestiges, which image God as being, God is the creative cause (Bonaventure probably has seminal forms in mind here). In the acts of likenesses, which image God by a conformity only possible by the possession of grace, God is the infused gift, that is, the one who indwells the soul by grace. In the acts of images, which image God by being rational, God is the moving cause, that is, the final end as well as the necessary medium ${ }^{51}$. With the middle claim, which in fact describes the highest state possible for creatures, Bonaventure crosses two boundaries at once. On the one hand, he crosses from epistemology into the prior ontological conditions that must ground it. On the other, he enters the forecourts of participation, for the likeness has God as the infused gift precisely as a created grace that is a participation in the divine being.

It is the ontological move that immediately comes to the fore in the next part of the argument, for it is as the image of God that the rational soul attains to the eternal ideas. However, we are fallen images, and so there must be a failure in our ability to attain the eternal reasons. But, because the image is never fully destroyed in us, we must attain them to some extent. Therefore our access to the ideas must be only preliminary and partial, varying in strength according to the degree of our conformity to God ${ }^{52}$. In the next life, when we will have lost the deformity of sin and gained the deiformity of God, we will see fully and clearly ${ }^{53}$.

49 "The nobility of knowledge requires it, I say, because there can be no certain knowledge except where there is immutability on the part of the object known and infallibility on the part of the knower" ([9], qu. 4, resp., p. 135).

50 "For a creature is related to God as a vestige, as an image, and as a likeness. In as far as it is a vestige, it is related to God as to its principle. In as far as it is an image, it is related to God as to its object. But in as far as it is a likeness, it is related to God as to an infused gift. And, therefore, every creature that proceeds from God is a vestige. Every creature that knows God is an image. In every creature in whom God dwells, and only such a creature, is a likeness. There are three levels of divine cooperation corresponding to these three degrees of relationship" ([9], qu. 4, resp., pp. 135-36).

51 "In any work accomplished by a creature in as far as it is a vestige, God cooperates as the creative principle. In any work accomplished by a creature in as far as it is a likeness-such as a work that is meritorious and pleasing to God-God cooperates in the manner of an infused gift. But in a work that proceeds from a creature in as far as it is an image, God cooperates as the moving cause" ([9], qu. 4, resp., p. 136).

52 "Since certain knowledge pertains to the rational spirit in as far as it is an image of God, it is in this sort of knowledge that the soul attains to the eternal reasons. But because it is never fully conformed to God in this life, it does not attain to the reasons clearly, fully, and distinctly, but only to a greater or lesser degree according to the degree of its conformity to God" ([9], qu. 4, resp., p. 136).

53 "Since, in the state of innocence, the image existed without the deformity of guilt but did not yet have the full deiformity of glory, it attained to them 'in part' but not 'obscurely.' In the state of fallen nature, the image is both deformed and lacking in deiformity. Therefore, it attains to them 'in part' and 'obscurely.' In the state of glory it lacks every deformity and it possesses its full conformity to God. Here, therefore, it attains to them in their fullness and clarity" ([9], qu. 4, resp., p. 136). Cf. ([17], p. 403). The introduction of deiformity, a favorite concept for Bonaventure, signals that, like Augustine, 
Bonaventure thinks that what this question has established is the necessity that the divine being indwell the rational mind: "It is clear from the previous question that the influence of the eternal light without its presence is not sufficient for certain knowledge." ([9], qu. 5, resp., p. 153). That is, he grounds the possibility of epistemological participation in the divine ideas in a prior ontological participation, the presence of God within the thinking creature.

Thus, the substantialization of the exemplary ideas not just as extra-mental realities but also as a hypostasis (the second person of the Trinity) transforms the entire discussion of exemplarity from one about knowledge into one about being. Plato's forms become not just objects of contemplation or explanatory necessities, but now causes in a sense that is as efficient as it is final. This will have consequences for how we read much of the rest of Bonaventure's corpus. Consider the Itinerarium, for instance: While it remains first and foremost about the elevation of the intellect in contemplation, it is also now seen to be mapping the progress of the human creature in every aspect of its reality towards God. The word "mind" in the title turns out to be metonymous.

The ramifications of this ontological move also rebound on the exposition given here, underscoring the ontological dimensions present in what was said and requiring the expansion of these key texts in Bonaventure beyond their explicit terms. The problem of the many and the one thus indeed belongs to the doctrine of creation, and its ideal dimension (that is to say, the dimension according to which it has to do with divine ideas) is secondary and illustrative of fundamental truths about the relation between God and creatures.

Once this is recognized, the question then stretches beyond its situation in the doctrine of creation to its proper situation in Christology. For, since Christ as the eternal ideas is the concrete ideal world, the ideas themselves are shown to pre-exist creation, and to be the very first plurification of the one. Thus the procession of a creaturely many from God is embraced in the prior generation of the Son. It is here that Bonaventure's doctrine of exemplarity comes into its own and does the work that he attributes to it in the Hexaemeron of grounding all metaphysics ${ }^{54}$, for now both the divine first principle and the creaturely first principle are found to coincide in the Son by reason of the exemplary relation of the former to the latter. Read closely, the question of the many and the one leads to the heart of Bonaventure's metaphysical and theological thinking, the one who in the divine and creaturely orders sums up the full possibilities of the One as the definitive and unsurpassable expression of every possibility.

Conflicts of Interest: The author declares no conflict of interest.

\section{References}

1. John F. Wippel. Metaphysical Themes in Thomas Aquinas II. Studies in Philosophy 47. Washington: Catholic University of America Press, 2007, pp. 152-71.

2. Alexander of Hales, Bernardinus Klumper, and Collegium S. Bonaventurae. Doctoris Irrefragabilis Alexandri de Hales Ordinis Minorum Summa Theological. Florence: Quaracchi, 1924, IaIIae, qu. 7, p. 16.

3. M. Hurley. "Illumination according to S. Bonaventure." Gregorianum 32 (1951): 388-404.

4. Zachary Hayes. "Indeed, for Bonaventure the most properly metaphysical question is that of exemplarity." In The Hidden Center. New York: Paulist Press, 1981, p. 13.

5. J. A. Wayne Hellman. Divine and Created Order in Bonaventure's Theology. Translated by Jay M. Hammond. St. Bonaventure: The Franciscan Institute, 2001, p. 67.

6. Saint Bonaventure. "Collationes in Hexaemeron." In Opera Omnia. Quaracchi: Collegium Sancti Bonaventurae, 1891, vol. 5, pp. 327-454.

the conceptuality is becoming increasingly participatory. At this point in this text, it is merely mentioned and not expounded upon, but it will play an ever larger role in the remaining questions of $D Q K C$.

54 "Haec est tota nostra metaphysica: de emanatione, de exemplaritate, de consummatione" (Hex. col. 1, no. 17) [6] ["This is our whole metaphysics: concerning emanation, exemplarity, and consummation"]. 
7. Leonard J. Bowman. “The Cosmic Exemplarism of St. Bonaventure.” Journal of Religion 55 (1975): 181-98. [CrossRef]

8. Saint Bonaventure. Opera Omnia. Edited by Collegium Sancti Bonaventurae. 10 vols. Quaracchi: Collegium Sancti Bonaventurae, 1882-1902.

9. Saint Bonaventure. Disputed Questions on the Knowledge of Christ. Translated by Zachary Hayes. St. Bonaventure: Franciscan Institute, 1992.

10. Joshua Benson. "Structure and Meaning in St. Bonaventure's Quaestiones Disputatae De Scientia Christi." Franciscan Studies 62 (2004): 67-90. [CrossRef]

11. Wendy Petersen Boring. “Revising Our Approach to 'Augustinian Illumination': A Reconsideration of Bonaventure's Quaestiones disputatae de scientia Christi IV, Aquinas' Summa theologiae Ia.84, 1-8, Henry of Ghent's, Summa quaestionum ordinarum, Q. 2, art. 1, 2." Franciscan Studies 68 (2010): 39-81.

12. Saint Augustine. Eighty-Three Different Questions. Translated by David L. Mosher. Washington: Catholic University of America Press, 1982, p. 79.

13. Saint Augustine. "The Fathers of the Church 78, 79, 88, 90, \& 92." In Tractates on the Gospel of John. Translated by John W. Retting. Washington: Catholic University of America Press, 1995.

14. Plato. "Phaedrus." In Plato: Complete Works. Edited by John M. Cooper. Indianapolis: Hackett Publishing Company, 1997, pp. 506-56.

15. William Preddy. Republic. Cambridge: Harvard University Press, 2013.

16. Thomas Aquinas. Commentary on the Posterior Analytics of Aristotle. Translated by Fabian R. Larcher. Albany: Magi Books, 1970, p. 189.

17. Etienne Gilson. The Philosophy of Saint Bonaventure. Translated by Dom Illtyd Trethowan. Patterson: St. Anthony Guild Press, 1965, pp. 132-33.

18. W. Norris Clarke. "The Problem of the Reality and Multiplicity of Divine Ideas in Christian Neoplatonism." In Neoplatonism and Christian Thought. Edited by Dominic J. O'Meara. Albany: State University of New York University Press, 1982, p. 123.

19. Ewert Cousins. Bonaventure and the Coincidence of Opposites. Chicago: Franciscan Herald Press, 1978, p. 116.

20. Mark G. Henninger. Relations: Medieval Theories 1250-1325. Oxford: Clarendon Press, 1989.

(C) 2016 by the author; licensee MDPI, Basel, Switzerland. This article is an open access article distributed under the terms and conditions of the Creative Commons Attribution (CC-BY) license (http://creativecommons.org/licenses/by/4.0/). 